Published in final edited form as:

J Org Chem. 2019 June 07; 84(11): 7443-7448. doi:10.1021/acs.joc.9b00518.

\title{
Cyclopropeniminium ions exhibit unique reactivity profiles with bioorthogonal phosphines
}

\author{
Tyler K. Heiss $^{\dagger}$, Jennifer A. Prescher ${ }^{\star}, \dagger, \ddagger, \S$ \\ tDepartments of Chemistry, Irvine, California 92697, United States \\ ¥Molecular Biology and Biochemistry, Irvine, California 92697, United States \\ §Pharmaceutical Sciences, University of California, Irvine, California 92697, United States
}

\begin{abstract}
We report a new ligation of cyclopropeniminium ions with bioorthogonal phosphines.

Cyclopropeniminium scaffolds are sufficiently stable in biological media and, unlike related isomers, react with functionalized phosphines via formal 1,2 -addition to a $\pi$-system. The ligation can be performed in aqueous solution and is compatible with existing bioorthogonal transformations. Such mutually compatible reactions are useful for multicomponent labeling.
\end{abstract}

\section{Graphical Abstract}

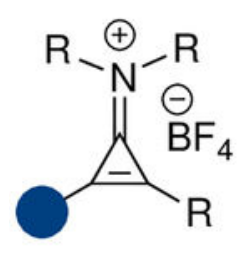

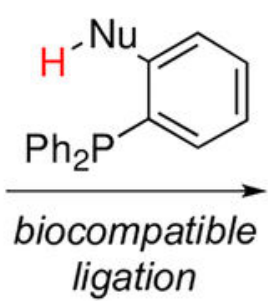

ligation

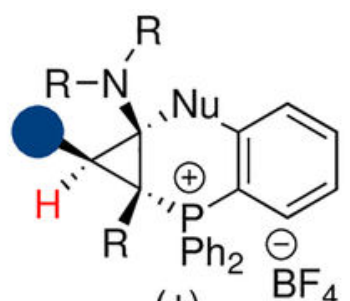

$( \pm)$

cyclopropane-

phosphonium adduct

Bioorthogonal chemistries are powerful tools for investigating biomolecules in living systems. ${ }^{1,2,3}$ These transformations involve reagents that react selectively with one another while remaining inert to biological species. Such chemistries have enabled numerous applications in vitro and in vivo, ${ }^{4}$ including biomolecule imaging, $, 5,6,7$ antibody-drug conjugation, ${ }^{8,9}$ and on-demand drug release. ${ }^{10,11,12}$ While the number and examples of bioorthogonal reagents continue to grow, limitations remain. ${ }^{13,14,15,16}$ Many scaffolds are too large for routine use with biological targets. Several of the most popular reagents also cross-react, hindering multicomponent labeling applications.

\footnotetext{
*Corresponding Author: jpresche@uci.edu.

The Supporting Information is available free of charge on the ACS publication website at DOI: http://pubs.acs.org. Additional images and NMR spectra (PDF).

$\mathrm{X}$-ray crystallographic data of compound $\mathbf{4 b}(\mathrm{CIF})$.

The authors declare no competing financial interests.
} 
The need for additional biocompatible reagents has inspired several pursuits over the years. 17,18 We recently reported cyclopropenone $(\mathrm{CpO})$ scaffolds with broad biological utility. ${ }^{19,20}$ $\mathrm{CpO}$ motifs are relatively small and stable, and they react selectively with functionalized (and bioorthogonal) phosphines. The ligation proceeds via a unique ketene-ylide intermediate that can be trapped with a variety of nucleophiles (Figure 1). ${ }^{21}$ Modifications to the cyclopropenone core can also alter reactivity. For example, we showed that sulfur heteroanalogs $(\mathrm{CpS})$ react more rapidly with substituted phosphines. ${ }^{22}$

We hypothesized that additional $\mathrm{CpO}$ analogs would broaden the scope of bioorthogonal reactivity. ${ }^{23,24} \mathrm{We}$ were drawn to cyclopropeniminium $\left(\mathrm{CpN}^{+}\right)$motifs based on their previous use in aqueous environments (Figure 2) ${ }^{25,26,27}$ Mono- $N$-substituted scaffolds (e.g., I-III) are not stable across the entire span of physiological pH values. ${ }^{28} \mathrm{~N}, \mathrm{~N}$-Disubstituted scaffolds, by contrast, are robust in a range of environments. ${ }^{29,30} \mathrm{CpN}^{+}$analogs have even been used as transfection reagents, suggesting compatibility with live cells. ${ }^{31}$ Furthermore, Hamada and colleagues showed that cyclopropenimines can react with triarylphosphines ${ }^{32}$ -reagents that have been well vetted in living systems. ${ }^{33,34,35}$

To evaluate $\mathrm{CpN}^{+}$motifs as candidate bioorthogonal reagents, we first synthesized a panel of symmetric probes (2a-c, Scheme 1). The desired motifs were obtained from the corresponding cyclopropenones via carbonyl activation and amine displacement. ${ }^{25,36}$ To access $\mathbf{2 a}-\mathbf{b}$, commercially available alkynes were reacted with difluorocarbene and then hydrolyzed using the general procedure of Olah, et al. ${ }^{20,37}$ The resulting cyclopropenones were then alkylated with Meerwein's reagent and subsequently treated with diethylamine. The aryl-substituted probe $\mathbf{2} \mathbf{c}$ was similarly accessed using commercially available diphenylcyclopropenone (1c). The overall yields for $\mathbf{2 a - c}$ were modest (Scheme S1), likely due to inefficient carbonyl activation. In each case, though, the remaining cyclopropenone could be readily recovered and re-subjected to the reaction sequence.

With the $\mathrm{CpN}^{+}$compounds in hand, we tested their stabilities in aqueous solution (Table S1). Compounds 2a-c were dissolved in buffer ( $\mathrm{pH}$ 7.4) and monitored via nuclear magnetic resonance (NMR) spectroscopy. Compounds 2a-b were stable for $>2$ d (Figures S1-S2), suggesting that they are suitable for biological use. Compound $\mathbf{2 c}$, by contrast, degraded over $24 \mathrm{~h}$ (Figure S3). Aryl-substituted $\mathrm{CpO}$ and $\mathrm{CpS}$ derivatives were also previously observed to be less stable than their bis-alkylated counterparts. ${ }^{20,22}$ Alkyl-substituted $\mathrm{CpN}^{+}$ probes are susceptible to degradation at higher $\mathrm{pH}$ values, but they are sufficiently long-lived for most applications $\left(\mathrm{t}_{1 / 2} \sim 13 \mathrm{~d}\right.$ at $\mathrm{pH} 8.4$, Table $\left.\mathrm{S} 2\right)$.

$\mathrm{CpN}^{+}$species were further examined in the presence of biologically relevant nucleophiles. Compounds 2a-c were incubated with amines or L-glutathione $(5 \mathrm{mM})$ in aqueous buffer and analyzed via NMR spectroscopy. Analogs $\mathbf{2 a}-\mathbf{b}$ were stable to exogenous amines, while 2c degraded under similar conditions (Figure S4-S6). The probes also exhibited varying degrees of reactivity with cellular thiols (Figures S7-S9). The half-life of $2 \mathbf{c}$ in the presence of L-glutathione was $\sim 7 \mathrm{~h}$, while the half-life of $\mathbf{2} \mathbf{b}$ (the most robust probe) was $\sim 41 \mathrm{~h}$. Despite being less stable than their $\mathrm{CpO}$ or $\mathrm{CpS}$ counterparts, $\mathrm{CpN}^{+}$probes are still suitable for use in non-reducing environments. ${ }^{20,22}$ The reaction between $\mathrm{CpN}^{+}$motifs and $\mathrm{L}$ - 
glutathione also liberates diethylammonium ions and bioorthogonal $\mathrm{CpO}$ scaffolds (Figure S7-S9), a process that could potentially be exploited for caged probe release.

$\mathrm{CpN}^{+}$analogs were hypothesized to react with functionalized phosphines via initial conjugate addition, ultimately undergoing ring opening similar to $\mathrm{CpO}$ and $\mathrm{CpS}$ derivatives (Figures 1 and S10). ${ }^{21,38,39}$ However, when $\mathbf{2 b}$ was incubated with phosphine 3a, the expected iminium product was not observed. Instead, a species with hemiaminal and phosphonium character was formed (4a, Figure 3A). Unfortunately, this product was found to revert to starting materials over time (Figure S11). A stable product was formed in the reaction of $\mathbf{2 b}$ and phosphine $\mathbf{3 b}$, and spectral analyses confirmed the presence of a cyclopropane-phosphonium adduct $(\mathbf{4 b}$, Figure $3 \mathrm{~B})$. The ${ }^{13} \mathrm{C}_{-}{ }^{31} \mathrm{P}$ coupling constants in the ${ }^{13} \mathrm{C}$ NMR spectrum were smaller than typical $J_{\mathrm{C}-\mathrm{P}}$ values (Figure $\mathrm{S} 12$ ). Cyclopropane carbon resonances are typically less affected by phosphorous nuclei. ${ }^{40}$ Additionally, ${ }^{1} \mathrm{H}-{ }^{1} \mathrm{H}$ COSY analysis revealed ${ }^{4} J_{\mathrm{H}-\mathrm{H}}$ coupling between the endocyclic methine and exocyclic methylene protons (Figure S13). Such long-range interactions have been observed in related structures. ${ }^{41}$ NMR analyses also suggested a single diastereomer was formed. Unfortunately, ${ }^{1} \mathrm{H}-{ }^{1} \mathrm{H}$ NOESY analysis could not distinguish among the possibilities (Figure S14). To unambiguously assign the stereochemistry, crystals of $\mathbf{4 b}$ were grown and analyzed via $X$ ray diffraction (Figure 3C). The structure confirmed the presence of a cyclopropanephosphonium bicycle (Figure S15, Table S2). Interestingly, the phosphorus and sulfur atoms were positioned on the same face of the ring as the methine proton.

The $\mathrm{CpN}^{+}$-phosphine ligation is also compatible with aqueous solvent. When $\mathbf{2 b}$ and phosphine $\mathbf{3 b}$ were mixed in $\mathrm{CH}_{3} \mathrm{CN}$ containing 50\% water, conversion to the expected adduct $\mathbf{4 b}$ was observed (Figures S16 and S17). Thiohemiaminal $\mathbf{4 b}$ was also stable over time in aqueous solution (Figure S18). To further probe the longevity of $\mathbf{4 b}$ in biological environs, we incubated the compound with L-glutathione (Figure S19). No degradation was observed over $24 \mathrm{~h}$. Related thiohemiaminal motifs comprise natural products and drug scaffolds, providing further evidence for their biocompatbility. ${ }^{42,43}$

The $\mathrm{CpN}^{+}$-phosphine ligation appears to be a highly unusual formal [4+2] bis-nucleophilic cycloaddition. The observed stereoselectivity can be explained via the mechanism shown in Figure 3D. We propose that phosphines $\mathbf{3} \mathbf{a}-\mathbf{b}$ first react with $\mathbf{2} \mathbf{b}$ to form enamine intermediates. Intramolecular proton transfer to a single face of the enamine dictates the observed stereochemistry. The deprotonated nucleophile can then attack the iminium species, generating a product with the phosphonium, nucleophile, and proton positioned on a single face of the cyclopropane ring.

The proposed mechanism is further supported by reactivity data. When $\mathbf{2 b}$ was incubated with a panel of functionalized phosphines (3a-e), reactions were only observed with the phenol and thiophenol conjugates (3a-b, Table 1 and Figure S20). No reaction was observed with the corresponding aniline probes $\mathbf{3 c}-\mathbf{d}$ (Figures S21 and S22), even when the less sterically encumbered $\mathrm{CpN}^{+} \mathbf{2 a}$ was used (Figure S23). The trends in reactivity correlate with the $\mathrm{p} K_{\mathrm{a}}$ values of the pendant nucleophiles, with efficient ligation observed with the most acidic residues ( $\mathrm{p} K_{\mathrm{a}} \sim 10,6$ for $\mathbf{3 a}-\mathbf{b}$, respectively). Intramolecular proton transfer is likely, as no ligation was observed when triphenylphosphine and exogenous thiophenol were 
combined with $\mathbf{2 b}$ (1:1, data not shown). Slight reactivity was observed only when $>100$ equivalents of thiophenol were present (Figure S24). Further evidence for the proposed mechanism comes from a lack of reactivity between $\mathbf{2 b}$ and phosphine $3 \mathbf{e}$. The more nucleophilic cyclohexyl phosphine ${ }^{44}$ has been shown to robustly ligate $\mathrm{CpO}$ and $\mathrm{CpS}$ derivatives ${ }^{20}$ In the case of $\mathrm{CpN}^{+}$species, though, no reactivity was observed (Figure S25), likely due to inefficient proton transfer (Figure S26).

The unique reactivity profile of $\mathrm{CpN}^{+}$motifs suggested that they could be used in tandem with other bioorthogonal reagents, even the structurally related cyclopropenones. $\mathrm{CpO}$ derivatives react quickly with phosphine $3 \mathbf{e}\left(k_{2}=0.34 \pm 0.06 \mathrm{M}^{-1} \mathrm{~s}^{-1}\right)$, but the same phosphine does not ligate $\mathbf{2 b} .{ }^{20}$ Conversely, phosphine $\mathbf{3 b}$ reacts readily with $\mathbf{2 b}\left(k_{2}=2.3\right.$ $\left.\pm 0.3 \times 10^{-3} \mathrm{M}^{-1} \mathrm{~s}^{-1}\right)$ but only sluggishly with similar cyclopropenones $\left(k_{2} \leq 10^{-5} \mathrm{M}^{-1} \mathrm{~s}^{-1}\right)$.

${ }^{20}$ To examine whether the $\mathrm{CpO}$ - and $\mathrm{CpN}^{+}$-phosphine ligations could be used concurrently, cyclopropenone $\mathbf{1 b}, \mathrm{CpN}^{+} \mathbf{2} \mathbf{b}$, and phosphines $\mathbf{3 b}$ and $\mathbf{3 e}$ were mixed together, and the reactions were monitored by ${ }^{1} \mathrm{H}$ - and ${ }^{31} \mathrm{P}-\mathrm{NMR}$ spectroscopy (Figures S27-S28). The expected ligation products formed, but a minor cross product was also observed (Figure S29). This product would be unlikely to form under biologically relevant conditions, when lower reactant concentrations are typically employed (Figure S29). Nonetheless, to showcase the exquisite compatibility of the $\mathrm{CpO}$ and $\mathrm{CpN}^{+}$probes, we performed the ligations sequentially. Compounds $\mathbf{1 b}, \mathbf{2} \mathbf{b}$, and $\mathbf{3 e}$ were first incubated, and only the expected carbonyl adduct was observed (Figures 4, S30-S32). Phosphine 3b was then added, and the cyclopropane adduct formed with no cross products observed. Considering that the $\mathrm{CpO}$ and $\mathrm{CpN}^{+}$scaffolds differ by just a single heteroatom, it is noteworthy that they can be used for multi-component labeling.

In conclusion, we investigated $N, N$-dialkylcyclopropeniminium $\left(\mathrm{CpN}^{+}\right)$ions as new bioorthogonal reagents. A panel of $\mathrm{CpN}^{+}$scaffolds was designed and synthesized. We tested the motifs in the presence of cellular nucleophiles, such as thiols and amines. We determined that dialkylated $\mathrm{CpN}^{+}$analogs react readily with functionalized phosphines to form cyclopropane-phosphonium adducts. The unique reactivity profiles of $\mathrm{CpN}^{+}$motifs enabled the reagents to be used in tandem with $\mathrm{CpO}$ probes. Collectively, cyclopropeniminium ions will be useful additions to the bioorthogonal toolkit and are poised for a variety of applications. Future work will address methods to install the probes on a range of target biomolecules for deployment in biological settings.

\section{EXPERIMENTAL SECTION}

\section{General synthetic procedures.}

Compounds $\mathbf{3 a},{ }^{45} \mathbf{3 b},{ }^{46} \mathbf{3} \mathbf{c},{ }^{47}$ and $\mathbf{3 d}-\mathbf{e}^{20}$ were prepared according to literature procedures. All reagents and solvents were used as received, unless otherwise specified. Anhydrous organic solvents were prepared by degassing with argon and passing through two $4 \times 36$ in. columns of anhydrous neutral A2 $\left(8 \times 12 \mathrm{mesh}\right.$; LaRoche Chemicals: activated at $350^{\circ} \mathrm{C}$ for $12 \mathrm{~h}$ under a flow of argon). Column chromatography was carried out using Silicycle $60 \AA$ (230-400 mesh) silica gel. Thin layer chromatography (TLC) was carried out with Merck Millipore $250 \mathrm{~mm}$ silica gel F-254 plates. Plates were visualized using UV light or $\mathrm{KMnO}_{4}$ 
stain. Organic solutions were concentrated under reduced pressure using a Büchi rotary evaporator.

${ }^{1} \mathrm{H},{ }^{13} \mathrm{C}$, and ${ }^{31} \mathrm{P}$ NMR spectra were obtained using Bruker instruments: DRX400, DRX500 equipped with a cryoprobe, or AVANCE600 equipped with a cryoprobe. ${ }^{1} \mathrm{H}$ NMR spectra were acquired at $400 \mathrm{MHz}, 500 \mathrm{MHz}$, or $600 \mathrm{MHz},{ }^{13} \mathrm{C}$ spectra were acquired at $125 \mathrm{MHz}$ or $151 \mathrm{MHz}$, and ${ }^{31} \mathrm{P}$ spectra were acquired at $162 \mathrm{MHz}$ or $243 \mathrm{MHz}$. Spectra were internally referenced to residual solvent signals $\left(7.27 \mathrm{ppm}\right.$ for ${ }^{1} \mathrm{H}$ and $77.16 \mathrm{ppm}$ for ${ }^{13} \mathrm{C}$ for $\mathrm{CDCl}_{3}, 3.31 \mathrm{ppm}$ for ${ }^{1} \mathrm{H}$ and $49.0 \mathrm{ppm}$ for ${ }^{13} \mathrm{C}$ for $\mathrm{CD}_{3} \mathrm{OD}, 1.94 \mathrm{ppm}$ for ${ }^{1} \mathrm{H}$ and $1.32 \mathrm{ppm}$ for ${ }^{13} \mathrm{C}$ for $\mathrm{CD}_{3} \mathrm{CN}$, and $4.79 \mathrm{ppm}$ for ${ }^{1} \mathrm{H}$ for $\mathrm{D}_{2} \mathrm{O}$ ). ${ }^{31} \mathrm{P}$ NMR spectra were referenced by indirect absolute chemical shift to residual protic solvent signals. All spectra were acquired at $298 \mathrm{~K}$. Chemical shifts are reported in ppm, and coupling constants $(J)$ are reported in $\mathrm{Hz}$. In some cases, internal standards were used (trimethylsilylacetylene for ${ }^{1} \mathrm{H}$ NMR and triphenylphosphine oxide for ${ }^{31} \mathrm{P}$ NMR). Mass spectra were acquired at the University of California, Irvine Mass Spectrometry Facility. Crystallographic analysis was performed at the University of California, Irvine X-Ray Crystallography Facility.

\section{Preparation of 2,3-dimethylcycloprop-2-en-1-one (1a).}

Compound 1a was prepared following the procedure of Shih, et al., with some modifications. ${ }^{19}$ To an oven-dried sealed tube containing a stir bar was added NaI (1.65 g, $11.0 \mathrm{mmol})$. The NaI was gently flame-dried under vacuum and then allowed to cool to room temperature. A solution of 2-butyne $(0.39 \mathrm{~mL}, 5.0 \mathrm{mmol})$ in anhydrous THF $(15 \mathrm{~mL})$ was added under an atmosphere of $\mathrm{N}_{2}$. Trifluoromethyltrimethylsilane $(1.47 \mathrm{~mL}, 10.0$ $\mathrm{mmol}$ ) was added, and the tube was sealed. The solution was stirred rapidly at room temperature for $2 \mathrm{~d}$, then diluted with $\mathrm{H}_{2} \mathrm{O}(60 \mathrm{~mL})$ and extracted into $\mathrm{CH}_{2} \mathrm{Cl}_{2}(3 \times 60 \mathrm{~mL})$. The combined organic layers were dried over $\mathrm{Na}_{2} \mathrm{SO}_{4}$, filtered, and concentrated in vacuo. The residue was dry-loaded onto silica ( $3 \mathrm{~g}$ ) and purified by flash column chromatography (eluting with $30 \%$ acetone/ $\left.\mathrm{CH}_{2} \mathrm{Cl}_{2}\right)$ to afford compound $\mathbf{1 a}$ as a yellow oil $(0.33 \mathrm{~g}, 4.0$ mmol, $80 \%$ ). Spectra matched those previously reported. ${ }^{48}$

\section{Preparation of 2,3-diethylcycloprop-2-en-1-one (1b).}

Compound $\mathbf{1 b}$ was prepared following the procedure of Shih, et al., with some modifications. ${ }^{19}$ To an oven-dried sealed tube containing a stir bar was added NaI ( $0.804 \mathrm{~g}$, $5.36 \mathrm{mmol})$. The NaI was gently flame-dried under vacuum and then allowed to cool to room temperature. A solution of 3-hexyne $(0.39 \mathrm{~mL}, 5.0 \mathrm{mmol})$ in anhydrous THF $(7.3 \mathrm{~mL})$ was added under an atmosphere of $\mathrm{N}_{2}$. Trifluoromethyltrimethylsilane $(0.72 \mathrm{~mL}, 4.9 \mathrm{mmol})$ was added, and the tube was sealed. The solution was stirred rapidly at room temperature for $2 \mathrm{~d}$, then diluted with $\mathrm{H}_{2} \mathrm{O}(30 \mathrm{~mL})$ and extracted into $\mathrm{CH}_{2} \mathrm{Cl}_{2}(3 \times 30 \mathrm{~mL})$. The combined organic layers were dried over $\mathrm{Na}_{2} \mathrm{SO}_{4}$, filtered, and concentrated in vacuo. The residue was dry-loaded onto silica ( $2 \mathrm{~g}$ ) and purified by flash column chromatography (eluting with 5\% acetone/ethyl acetate) to afford compound $\mathbf{1 b}$ as a yellow oil $(0.24 \mathrm{~g}, 4.0 \mathrm{mmol}, 91 \%)$. Spectra matched those previously reported. ${ }^{49}$ 


\section{Preparation of $\mathrm{N}$-(2,3-dimethylcycloprop-2-en-1-ylidene)- $\mathrm{N}$-ethylethanaminium tetrafluoroborate (2a).}

To an oven-dried round bottom flask containing a stir bar was added cyclopropenone 1a (25 $\mathrm{mg}, 0.31 \mathrm{mmol})$ and anhydrous $\mathrm{CH}_{2} \mathrm{Cl}_{2}(2 \mathrm{~mL})$ under an atmosphere of $\mathrm{N}_{2}$.

Triethyloxonium tetrafluoroborate $\left(1 \mathrm{M}\right.$ in $\mathrm{CH}_{2} \mathrm{Cl}_{2}, 0.31 \mathrm{~mL}, 0.31 \mathrm{mmol}$ ) was added dropwise, and the reaction was stirred at room temperature for $20 \mathrm{~min}$. A solution of diethylamine $(0.032 \mathrm{~mL}, 0.31 \mathrm{mmol})$ was prepared in anhydrous $\mathrm{CH}_{2} \mathrm{Cl}_{2}(1 \mathrm{~mL})$. Both solutions were chilled to $0^{\circ} \mathrm{C}$. The diethylamine solution was then added dropwise to the solution of alkylated 1a, and the reaction was monitored by TLC ( $25 \%$ acetone $/ \mathrm{CH}_{2} \mathrm{Cl}_{2}$ ). After $2 \mathrm{~h}$, the reaction was concentrated in vacuo, and the residue was purified by flash column chromatography (eluting with $5 \%$ toluene $/ 25 \%$ acetone $/ \mathrm{CH}_{2} \mathrm{Cl}_{2}$ ) to afford compound 2a as an orange oil (43 mg, $0.19 \mathrm{mmol}, 22 \%)$. ${ }^{1} \mathrm{H}$ NMR (400 $\left.\mathrm{MHz}, \mathrm{CD}_{3} \mathrm{OD}\right) \delta$ $3.64(\mathrm{q}, J=7.3 \mathrm{~Hz}, 4 \mathrm{H}), 2.52(\mathrm{~s}, 6 \mathrm{H}), 1.36$ (t, $J=7.3 \mathrm{~Hz}, 6 \mathrm{H}) .{ }^{13} \mathrm{C}\left\{{ }^{1} \mathrm{H}\right\} \mathrm{NMR}(151 \mathrm{MHz}$, $\mathrm{CD}_{3} \mathrm{OD}$ ) $\delta 150.0,143.5,47.8,12.2,8.5$. HRMS (ESI-TOF) $\mathrm{m} / \mathrm{z}$ calculated for $\mathrm{C}_{9} \mathrm{H}_{16} \mathrm{~N}$ [M] +138.1283 , found 138.1281 .

\section{Preparation of $\mathrm{N}$-(2,3-diethylcycloprop-2-en-1-ylidene)- $\mathrm{N}$-ethylethanaminium tetrafluoroborate $(2 b)$.}

To an oven-dried round-bottom flask containing a stir bar was added cyclopropenone $\mathbf{1 b}$ (39 $\mathrm{mg}, 0.35 \mathrm{mmol})$ and anhydrous $\mathrm{CH}_{2} \mathrm{Cl}_{2}(3 \mathrm{~mL})$ under an atmosphere of $\mathrm{N}_{2}$.

Triethyloxonium tetrafluoroborate $\left(1 \mathrm{M}\right.$ in $\left.\mathrm{CH}_{2} \mathrm{Cl}_{2}, 0.35 \mathrm{~mL}, 0.35 \mathrm{mmol}\right)$ was added dropwise, and the reaction was stirred at room temperature for $20 \mathrm{~min}$. A solution of diethylamine $(0.051 \mathrm{~mL}, 0.50 \mathrm{mmol})$ was prepared in anhydrous $\mathrm{CH}_{2} \mathrm{Cl}_{2}(1 \mathrm{~mL})$. Both solutions were chilled to $0{ }^{\circ} \mathrm{C}$. The diethylamine solution was then added dropwise to the solution of alkylated $\mathbf{1 b}$, and the reaction was monitored by TLC (10\% acetone/ $\mathrm{CH}_{2} \mathrm{Cl}_{2}$ ). After $2 \mathrm{~h}$, the reaction was concentrated in vacuo, and the residue was purified by flash column chromatography (eluting with $5 \%$ toluene/10\% acetone $/ \mathrm{CH}_{2} \mathrm{Cl}_{2}$ ) to afford compound $\mathbf{2 b}$ as a yellow oil (31 mg, $0.12 \mathrm{mmol}, 35 \%)$. ${ }^{1} \mathrm{H}$ NMR $\left(400 \mathrm{MHz}, \mathrm{CD}_{3} \mathrm{CN}\right): \delta$ $3.58(\mathrm{q}, J=7.3 \mathrm{~Hz}, 4 \mathrm{H}), 2.84(\mathrm{qt}, J=7.5,1.1 \mathrm{~Hz}, 4 \mathrm{H}) 1.33(\mathrm{t}, J=7.5 \mathrm{~Hz}, 6 \mathrm{H}), 1.29$ (t, $J=$ $7.3 \mathrm{~Hz}, 6 \mathrm{H}) .{ }^{13} \mathrm{C}\left\{{ }^{1} \mathrm{H}\right\} \mathrm{NMR}\left(151 \mathrm{MHz}, \mathrm{CD}_{3} \mathrm{CN}\right): \delta 150.8,148.3,49.6,18.5,13.6,11.0$. HRMS (ESI-TOF) $\mathrm{m} / \mathrm{z}$ calcd for $\mathrm{C}_{11} \mathrm{H}_{20} \mathrm{~N}[\mathrm{M}]^{+} 166.1596$, found 166.1598 .

\section{Preparation of $\mathrm{N}$-(2,3-diphenylcycloprop-2-en-1-ylidene)- $\mathrm{N}$-ethylethanaminium tetrafluoroborate $(2 \mathrm{c})$.}

To an oven-dried round bottom flask containing a stir bar was added cyclopropenone 1c (53 $\mathrm{mg}, 0.26 \mathrm{mmol})$ and anhydrous $\mathrm{CH}_{2} \mathrm{Cl}_{2}(3 \mathrm{~mL})$ under an atmosphere of $\mathrm{N}_{2}$.

Triethyloxonium tetrafluoroborate $\left(1 \mathrm{M}\right.$ in $\left.\mathrm{CH}_{2} \mathrm{Cl}_{2}, 0.26 \mathrm{~mL}, 0.26 \mathrm{mmol}\right)$ was added dropwise, and the reaction was stirred at room temperature for $20 \mathrm{~min}$. A solution of diethylamine $(0.037 \mathrm{~mL}, 0.34 \mathrm{mmol})$ was prepared in anhydrous $\mathrm{CH}_{2} \mathrm{Cl}_{2}(1 \mathrm{~mL})$. Both solutions were chilled to $0^{\circ} \mathrm{C}$. The diethylamine solution was then added dropwise to the solution of alkylated $1 \mathrm{c}$ at $0^{\circ} \mathrm{C}$, and the reaction was monitored by TLC (5\% acetone/ $\mathrm{CH}_{2} \mathrm{Cl}_{2}$ ). After $2 \mathrm{~h}$, the reaction was concentrated in vacuo, and the residue was purified by flash column chromatography (eluting with $5 \%$ toluene/15\% acetone $/ \mathrm{CH}_{2} \mathrm{Cl}_{2}$ ) to afford compound $2 \mathrm{c}$ as a yellow solid (13 $\mathrm{mg}, 0.035 \mathrm{mmol}, 14 \%) .{ }^{1} \mathrm{H} \mathrm{NMR}\left(400 \mathrm{MHz}, \mathrm{CD}_{3} \mathrm{CN}\right) \delta$ 
8.15-8.11 (m, 4H), 7.88-7.83 (m, 2H), 7.80-7.74 (m, 4H), 3.96 (q, J=7.3 Hz, 4H), 1.47 (t, $J=7.3 \mathrm{~Hz}, 6 \mathrm{H}) .{ }^{13} \mathrm{C}\left\{{ }^{1} \mathrm{H}\right\} \mathrm{NMR}\left(151 \mathrm{MHz}, \mathrm{CD}_{3} \mathrm{CN}\right) \delta 144.8,136.2,135.8,133.7,131.1$, 121.5, 50.7, 14.6. HRMS (ESI-TOF) $\mathrm{m} / \mathrm{z}$ calculated for $\mathrm{C}_{19} \mathrm{H}_{20} \mathrm{~N}[\mathrm{M}]^{+} 262.1596$, found 262.1593.

\section{Preparation of 1a-(diethylamino)-1,7a-diethyl-7,7-diphenyl-1,1a,7,7a- tetrahydrobenzo[b]cyclopropa[e][1,4]-oxaphosphinin-7-ium tetrafluoroborate (4a).}

To an oven-dried scintillation vial was added cyclopropeniminium $2 \mathrm{~b}(18.3 \mathrm{mg}, 0.072$ $\mathrm{mmol}$ ) and anhydrous $\mathrm{MeCN}$ (2.0 mL). Once dissolved, phosphine 3a (40 mg, $0.144 \mathrm{mmol})$ was added and the reaction vessel was flushed with Ar. The reaction was then stirred under an inert atmosphere, and reaction was monitored by TLC $\left(10 \%\right.$ acetone $\left./ \mathrm{CH}_{2} \mathrm{Cl}_{2}\right)$. After 72 $\mathrm{h}$, the solution was concentrated in vacuo and purification was attempted by flash column chromatography (eluting with $5 \%$ toluene/ $10 \%$ acetone/ $\mathrm{CH}_{2} \mathrm{Cl}_{2}$ ). While isolable, compound $4 \mathrm{a}$ was found to revert to starting materials $2 \mathrm{~b}$ and $3 \mathrm{a}$ at room temperature, preventing full characterization of compound $4 \mathrm{a}$ (see Figure S11). ${ }^{31} \mathrm{P}\left\{{ }^{1} \mathrm{H}\right\} \mathrm{NMR}\left(162 \mathrm{MHz}, \mathrm{CD}_{3} \mathrm{CN}\right) \delta$ 16.3. HRMS (ESI-TOF) $\mathrm{m} / \mathrm{z}$ calculated for $\mathrm{C}_{29} \mathrm{H}_{35} \mathrm{NPO}[\mathrm{M}]^{+} 444.2456$, found 444.2500 .

\section{Preparation of 1a-(diethylamino)-1,7a-diethyl-7,7-diphenyl-1,1a,7,7a- tetrahydrobenzo[b]cyclopropa[e][1,4]-thiaphosphinin-7-ium tetrafluoroborate (4b).}

To an oven-dried scintillation vial was added cyclopropeniminium $2 \mathrm{~b}(26 \mathrm{mg}, 0.11 \mathrm{mmol})$. and anhydrous MeCN (5.3 mL). Once dissolved, phosphine $3 \mathrm{~b}$ (34 mg, $0.12 \mathrm{mmol}$ ) was added and the reaction vessel was flushed with Ar. The reaction was then stirred under an inert atmosphere, and the reaction was monitored by TLC $\left(10 \%\right.$ acetone $\left./ \mathrm{CH}_{2} \mathrm{Cl}_{2}\right)$. After 12

$\mathrm{h}$, the solution was then concentrated in vacuo and purified by flash column chromatography (eluting with $5 \%$ toluene/10\% acetone/ $\mathrm{CH}_{2} \mathrm{Cl}_{2}$ ) to afford compound $4 \mathrm{~b}$ as a white solid (27 $\mathrm{mg}, 0.049 \mathrm{mmol}, 46 \%) .{ }^{1} \mathrm{H}$ NMR (500 MHz, $\left.\mathrm{CD}_{3} \mathrm{OD}\right) \delta$ 7.99-7.96 (m, 2H), 7.89-7.79 (m, $8 \mathrm{H}), 7.72-7.67(\mathrm{~m}, 2 \mathrm{H}), 7.58-7.54(\mathrm{~m}, 1 \mathrm{H}), 7.33(\mathrm{dd}, J=12.4,7.9 \mathrm{~Hz}, 1 \mathrm{H}), 2.97$ (dq, $J=$ $15.1,7.5 \mathrm{~Hz}, 1 \mathrm{H}), 2.89$ (dq, $J=13.8,7.0 \mathrm{~Hz}, 1 \mathrm{H}), 2.69$ (dq, $J=13.8,7.0 \mathrm{~Hz}, 1 \mathrm{H}), 2.47-2.28$ (m, 4H), 1.99 (app quint, $J=7.1 \mathrm{~Hz}, 1 \mathrm{H}), 1.24$ (t, $J=7.4 \mathrm{~Hz}, 3 \mathrm{H}$ ), 1.21 (t, $J=7.2 \mathrm{~Hz}, 3 \mathrm{H}$ ), $1.04(\mathrm{t}, J=7.3 \mathrm{~Hz}, 3 \mathrm{H}), 0.68(\mathrm{t}, J=7.5 \mathrm{~Hz}, 3 \mathrm{H}) .{ }^{31} \mathrm{P}\left\{{ }^{1} \mathrm{H}\right\}$ NMR $\left(243 \mathrm{MHz}, \mathrm{CD}_{3} \mathrm{OD}\right) \delta 20.5$. ${ }^{13} \mathrm{C}\left\{{ }^{1} \mathrm{H}\right\}$ NMR $\left(151 \mathrm{MHz}, \mathrm{CD}_{3} \mathrm{OD}\right) \delta 144.6(\mathrm{~d}, J=6.5 \mathrm{~Hz}), 137.3(\mathrm{~d}, J=10.5 \mathrm{~Hz}), 137.3$ (d, $J=2.3 \mathrm{~Hz}), 136.7-136.6$ (m), 136.1 (d, $J=9.8 \mathrm{~Hz}), 135.4$ (d, $J=9.8 \mathrm{~Hz}), 133.0$ (d, $J=$ $7.5 \mathrm{~Hz}), 132.0$ (d, $J=12.9 \mathrm{~Hz}), 132.0(\mathrm{~d}, J=12.5 \mathrm{~Hz}), 129.3(\mathrm{~d}, J=12.3 \mathrm{~Hz}), 119.3(\mathrm{~d}, J=$ $96.4 \mathrm{~Hz}), 118.3(\mathrm{~d}, J=89.0 \mathrm{~Hz}), 117.6(\mathrm{~d}, J=85.5 \mathrm{~Hz}), 69.8(\mathrm{~d}, J=3.9 \mathrm{~Hz}), 49.7,49.6,41.4$ (d, $J=4.0 \mathrm{~Hz}), 35.2(\mathrm{~d}, J=72.5 \mathrm{~Hz}), 20.4(\mathrm{~d}, J=5.0 \mathrm{~Hz}), 18.4$ (d, $J=1.1 \mathrm{~Hz}), 15.2,14.7$, 14.4, 12.0. HRMS (ESI-TOF) $\mathrm{m} / \mathrm{z}$ calculated for $\mathrm{C}_{29} \mathrm{H}_{35} \mathrm{NPS}[\mathrm{M}]^{+} 460.2228$, found 460.2208 .

\section{Reaction compatibility of $\mathrm{CpO}$ - and $\mathrm{CpN}^{+}$-phosphine ligations.}

For the simultaneous ligation experiment, cyclopropenone $1 \mathbf{b}(20 \mathrm{mM})$, cyclopropeniminium ion $\mathbf{2 b}(20 \mathrm{mM})$, cyclohexyl phosphine $\mathbf{3 e}(20 \mathrm{mM})$, thiophenol phosphine $3 \mathbf{b}(20 \mathrm{mM})$, and trimethylsilylacetylene (4 mM, internal standard for ${ }^{1} \mathrm{H}$ NMR) were combined in $\mathrm{CD}_{3} \mathrm{CN}$ (containing $14 \% \mathrm{C}_{6} \mathrm{D}_{6}$ ) in an oven-dried NMR tube. The reaction was monitored by ${ }^{1} \mathrm{H}$ - and ${ }^{31} \mathrm{P}\left\{{ }^{1} \mathrm{H}\right\}$-NMR spectroscopy. For the sequential ligation 
experiment, cyclopropenone $\mathbf{1 b}(20 \mathrm{mM})$, cyclopropeniminium ion $\mathbf{2 b}(20 \mathrm{mM})$, phosphine 3e (24 mM), triphenylphosphine oxide ( $2 \mathrm{mM}$, internal standard), and trimethylsilylacetylene ( $2 \mathrm{mM}$, internal standard) were combined in $\mathrm{CD}_{3} \mathrm{CN}$ (containing $20 \% \mathrm{C}_{6} \mathrm{D}_{6}$ ) in an oven-dried NMR tube. The reaction was monitored by ${ }^{1} \mathrm{H}-$ and ${ }^{31} \mathrm{P}-\mathrm{NMR}$ spectroscopy. When $\mathbf{1 b}$ was consumed, phosphine $\mathbf{3 b}(18 \mathrm{mM})$ was added to the solution. The reaction was monitored by ${ }^{1} \mathrm{H}$ - and ${ }^{31} \mathrm{P}\left\{{ }^{1} \mathrm{H}\right\}$-NMR spectroscopy.

\section{Supplementary Material}

Refer to Web version on PubMed Central for supplementary material.

\section{ACKNOWLEDGMENTS}

This work was supported by the U.S. National Institutes of Health (R01 GM126226 to J.A.P.) and the Alfred P. Sloan Foundation (J.A.P.). We thank the Heyduk, Nowick, and Chamberlin laboratories for providing reagents and equipment, Phil Dennison (UCI) for assistance with NMR experiments, Benjamin Katz (UCI) and Felix Grün (UCI) for help with mass spectrometry experiments, and Joseph Ziller (UCI) and Michael Wojnar (UCI) for assistance with X-ray crystallography experiments. We thank Profs. Dave Van Vranken and James Nowick for helpful discussions on product structures and mechanism. We also thank members of the Prescher lab for manuscript edits and helpful discussions.

\section{REFERENCES}

1. Sletten EM; Bertozzi CR Bioorthogonal chemistry: fishing for selectivity in a sea of functionality. Angew. Chem. Int. Ed 2009, 48, 6974-6998.

2. Lang K; Chin JW Bioorthogonal reactions for labeling proteins. ACS Chem. Biol 2014, 9, 16-20. [PubMed: 24432752]

3. Patterson DM; Nazarova LA; Prescher JA Finding the right (bioorthogonal) chemistry. ACS Chem. Biol 2014, 9, 592-605. [PubMed: 24437719]

4. Grammel M; Hang HC Chemical reporters for biological discovery. Nat. Chem. Biol 2013, 9, 475484. [PubMed: 23868317]

5. Laughlin ST; Baskin JM; Amacher SL; Bertozzi CR In vivo imaging of membrane-associated glycans in developing zebrafish. Science 2008, 320, 664-667. [PubMed: 18451302]

6. Alvarez-Castelao B; Schanzenbächer CT; Hanus C; Glock C; tom Dieck S; Dörrbaum AR; Bartnik I; Nassim-Assir B; Ciirdaeva E; Mueller A; Dieterich DC; Tirrell DA; Langer JD; Schuman EM Cell-type-specific metabolic labeling of nascent proteomes in vivo. Nat. Biotechnol 2017, 35, 11961201. [PubMed: 29106408]

7. Krogager TP; Ernst RJ; Elliot TS; Calo L; Beránek V; Ciabatti E; Spillantini MG; Tripodi M; Hastings MH; Chin JW Labeling and identifying cell-type-specific proteomes in the mouse brain. Nat. Biotechnol 2018, 36, 156-159. [PubMed: 29251727]

8. Oller-Salvia B; Kym G; Chin JW Rapid and efficient generation of stable antibody-drug conjugates via an encoded cyclopropene and an inverse-electron-demand Diels-Alder reaction. Angew. Chem. Int. Ed 2018, 57, 2831-2834.

9. Agarwal P; van der Weijden J; Sletten EM; Rabuka D; Bertozzi CR A Pictet-Spengler ligation for protein chemical modification. Proc. Natl. Acad. Sci. U. S. A 2013, 110, 46-51. [PubMed: 23237853]

10. Versteegen RM; Rossin R; ten Hoeve W; Janssen HM; Robillard MS Click to release: instantaneous doxorubicin elimination upon tetrazine ligation. Angew. Chem. Int. Ed 2013, 52, 14112-14116.

11. Mejia Oneto JM; Khan I; Seeblad L; Royzen M In vivo bioorthogonal chemistry enables local hydrogel and systemic pro-drug to treat soft tissue sarcoma. ACS Cent. Sci 2016, 476-482. [PubMed: 27504494] 
12. Li J; Chen PR Development and application of bond cleavage reactions in bioorthogonal chemistry. Nat. Chem. Biol 2016, 12, 129-137. [PubMed: 26881764]

13. Patterson DM; Prescher JA Orthogonal bioorthogonal chemistries. Curr. Opin. Chem. Biol 2015, 28, 141-149. [PubMed: 26276062]

14. Murrey HE; Judkins JC; am Ende CW; Ballard TE; Fang Y; Riccardi K; Di L; Guilmette ER; Schwartz JW; Fox JM; Johnson DS Systemic evaluation of bioorthogonal reactions in live cells with clickable HaloTag ligands: implications for intracellular imaging. J. Am. Chem. Soc 2015, 137, 11461-11475. [PubMed: 26270632]

15. Shih H-W; Kamber DN; Prescher JA Building better bioorthogonal reactions. Curr. Opin. Chem. Biol 2014, 21, 103-111. [PubMed: 25086220]

16. Devaraj NK The future of bioorthogonal chemistry. ACS Cent. Sci 2018, 4, 952-959. [PubMed: 30159392]

17. Row RD; Prescher JA Constructing new bioorthogonal reagents and reactions. Acc. Chem. Res 2018, 51, 1073-1081. [PubMed: 29727171]

18. Wu H; Devaraj NK Advances in tetrazine bioorthogonal chemistry driven by the synthesis of novel tetrazines and dienophiles. Acc. Chem. Res 2018, 51, 1249-1259. [PubMed: 29638113]

19. Shih H-W; Prescher JA A bioorthogonal ligation of cyclopropenones mediated by triarylphosphines. J. Am. Chem. Soc 2015, 137 10036-10039. [PubMed: 26252114]

20. Row RD; Shih H-W; Alexander AT; Mehl RA; Prescher JA Cyclopropenones for metabolic targeting and sequential bioorthogonal labeling. J. Am. Chem. Soc 2017, 139, 7370-7375. [PubMed: 28478678]

21. Hamada A; Takizawa T Reactions of diphenylcyclopropenone with trivalent phosphorous compounds. Chem. Pharm. Bull 1975, 23, 2933-2938.

22. Row RD; Prescher JA A cyclopropenethione-phosphine ligation for rapid biomolecule labeling. Org. Lett 2018, 20, 5614-5617. [PubMed: 30207474]

23. Komatsu K; Kitagawa T Cyclopropenylium cations, cyclopropenones, and heteroanaloguesrecent advances. Chem. Rev 2003, 103, 1371-1428. [PubMed: 12683786]

24. Potts KT; Baum JS The chemistry of cyclopropenones. Chem. Rev 1974, 74, 189-213.

25. Breslow R; Eicher T; Krebs A; Peterson RA; Posner J Diphenylcyclopropenone. J. Am. Chem. Soc 1965, 87, 1320-1325.

26. Mirabdolbaghi R; Dudding T; Stamatatos T A class of phase-transfer catalyst with interionic strain: insight into the bonding of disubstituted $\mathrm{N}$ - vs carbene-stabilized $\mathrm{N}^{\mathrm{I}}$-centered cations. Org. Lett 2014, 16, 2790-2793. [PubMed: 24857779]

27. Bandar JS; Tanaset A; Lambert TH Phase-transfer and other types of catalysis with cyclopropenium ions. Chem. Eur. J 2015, 21, 7365-7368. [PubMed: 25820636]

28. Yoshida H; Ohtsuka H; Yoshida K; Totani Y; Ogata T; Matsumoto K Cyclopropenone oximes: preparation and reaction with isocyanates. Bull. Chem. Soc. Jpn 1988, 61, 4347-4351.

29. Bandar JS; Lambert TH Aminocyclopropenium ions: synthesis, properties, and applications. Synthesis 2013, 45, 2485-2498.

30. Levandowski BJ; Hamlin TA; Helgeson RC; Bickelhaupt FM; Houk KN Origins of the endo and exo selectivities in cyclopropenone, iminocyclopropene, and triafulvene Diels-Alder cycloadditions. J. Org. Chem 2018, 83, 3164-3170. [PubMed: 29470085]

31. Freyer JL; Brucks SD; Gobieski GS; Russell ST; Yozwiak CE; Sun M; Chen Z; Jiang Y; Bandar JS; Stockwell BR; Lambert TH; Campos LM Clickable poly(ionic liquids): a materials platform for transfection. Angew. Chem. Int. Ed 2016, 55, 12382-12386.

32. Hamada A; Takizawa T Reactions of $N$-( $p$-toluenesulfonyl)-diphenylcyclopropenimine with trivalent phosphorous compounds. Chem. Pharm. Bull 1975, 23, 2987-2989.

33. Saxon E; Bertozzi CR Cell surface engineering by a modified Staudinger reaction. Science 2000, 287, 2007-2010. [PubMed: 10720325]

34. Prescher JA; Dube DH; Bertozzi CR Chemical remodelling of cell surfaces in living animals. Nature 2004, 430, 873-878. [PubMed: 15318217]

35. Köhn M; Breinbauer R The Staudinger ligation—a gift to chemical biology. Angew. Chem. Int. Ed 2004, 43, 3106-3116. 
36. Eicher T; Graf R; Konzmann H; Pick R Syntheses and reactions of 2,3-diaryl- and 2,3dialkylcyclopropenone imines. Synthesis 1987, 10, 887-892.

37. Wang F; Luo T; Hu J; Hema SK; Jog PV; Ganesh SK; Surya Prakash GK; Olah GA Synthesis of gem-difluorinated cyclopropanes and cyclopropenes: trifluoromethyltrimethylsilane as a difluorocarbene source. Angew. Chem. Int. Ed 2011, 50, 7153-7157.

38. Pilli RA; Rodrigues JAR; Kascheras A Reaction of $N$-( $p$-tolylsulfonyl)diphenylcyclopropenimine with pyridinium and isoquinolinium ylides. J. Org. Chem 1983, 48, 1084-1091.

39. Matsumara N; Tanaka H; Yagyu Y; Mizuno K; Inoue H; Takada K; Yasui M; Iwasaki F Synthesis and reactivity of new 1,4-bis(alkylthio)-3,6-diarylthieno[3,4-c]thiophene derivatives. J. Org. Chem 1998, 63, 163-168. [PubMed: 11674057]

40. Bastanov AS; Davidson MG; Fernández I; Howard JAK; López-Ortiz F; Price RD One pot synthesis of chiral $N$-phosphine substituted imino-phosphorane: X-ray structure and in situ NMR study. J. Chem. Soc., Perkin Trans. 1 2000, 0, 4237-4239.

41. Sproviero EM; Ferrara A; Contreras RH; Burton $\mathrm{G}^{1} \mathrm{H}-{ }^{1} \mathrm{H}$ Long range couplings in fused cyclopropanes. NMR spectral assignment and conformation of 17,18-cyclosteroids. J. Chem. Soc., Perkin Trans. 2 1996, 0, 933-938.

42. Buchholz M; Hamann A; Aust S; Brandt W; Böhme L; Hoffman T; Schilling S; Demuth H-U; Heiser U Inhibitors for human glutaminyl cyclase by structure based design and bioisosteric replacement. J. Med. Chem 2009, 52, 7069-7080. [PubMed: 19863057]

43. Igarashi Y; Asano D; Sawamura M; In Y; Ishida T; Imoto M Ulbactins F and G, polycyclic thiazoline derivatives with tumor cell migration inhibitory activity from Brevibacillus sp. Org. Lett 2016, 18, 1658-1661. [PubMed: 26998643]

44. Henderson Wm. A.; Buckler, S. A. The nucleophilicity of phosphines. J. Am. Chem. Soc 1960, 82, 5794-5800.

45. Herd O; Hessler A; Hingst M; Machnitzki P; Tepper M; Stelzer O Palladium catalyzed P-C coupling - a powerful tool for the syntheses of hydrophilic phosphines. Catal. Today 1998, 42, 413-420.

46. Figuly GD; Loop CK; Martin JC Directed ortho-lithiation of lithium thiophenolate. New methodology for the preparation of ortho-substituted thiophenols and related compounds. J. Am. Chem. Soc 1989, 111, 654-658.

47. Gelman D; Jiang L; Buchwald SL Copper-catalyzed C-P bond construction via direct coupling of secondary phosphines and phosphites with aryl and vinyl halides. Org. Lett 2003, 5, 2315-2318. [PubMed: 12816437]

48. Breslow R; Altman LJ Methylcyclopropenone and related compounds. J. Am. Chem. Soc 1966, 88, 504-509.

49. Netland KA; Gundersen L-L; Rise F An improved synthesis of dialkylcyclopropenones. Synth. Comm 2000, 30, 1767-1777. 


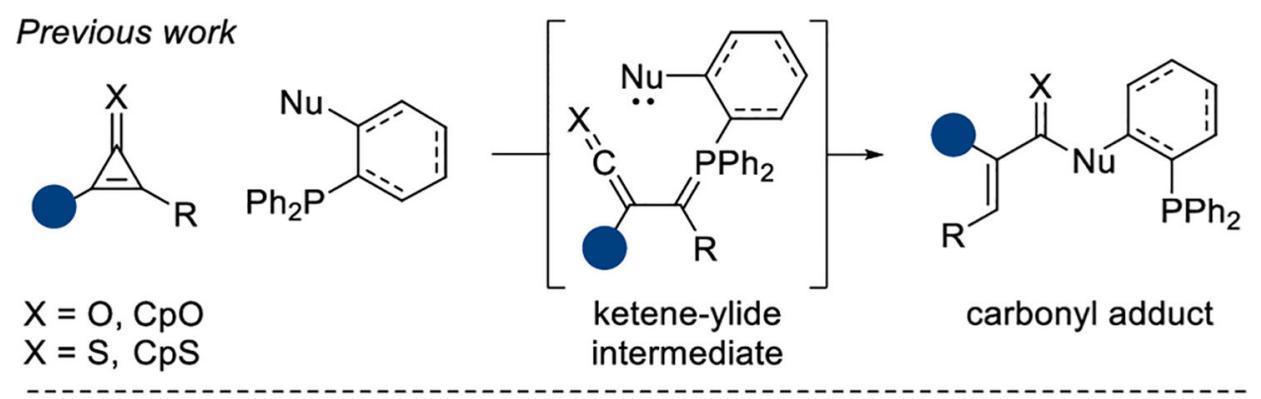

This work<smiles></smiles>

$\mathrm{CpN}^{+}$<smiles>Pc1ccccc1NNc1ccccc1</smiles><smiles>[R]C1C([R])C1N([R])F</smiles>

$( \pm$ phosphonium adduct

Figure 1.

Cyclopropenone analogs can be ligated with bioorthogonal phosphines. Cyclopropenone $(\mathrm{CpO})$ and cyclopropenethione $(\mathrm{CpS})$ scaffolds react with substituted phosphines to provide carbonyl adducts. In this work, we examine the reactivity of analogous cyclopropeniminium $\left(\mathrm{CpN}^{+}\right)$ions. 

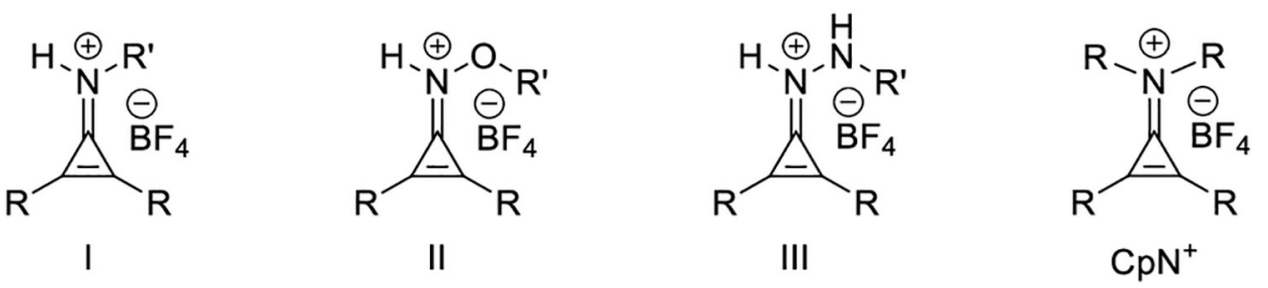

Figure 2.

Cyclopropeniminium analogs are candidate bioorthogonal probes. 
A

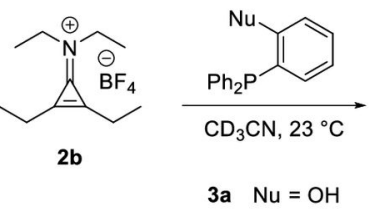

3b $\mathrm{Nu}=\mathrm{SH}$

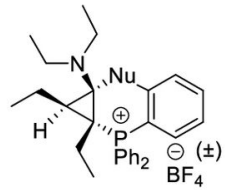

$4 \mathbf{a ~ N u}=0,97 \%$ (NMR)

$4 \mathrm{~b} \mathrm{Nu}=\mathrm{S}, 98 \%(\mathrm{NMR})^{\mathrm{a}}$

B
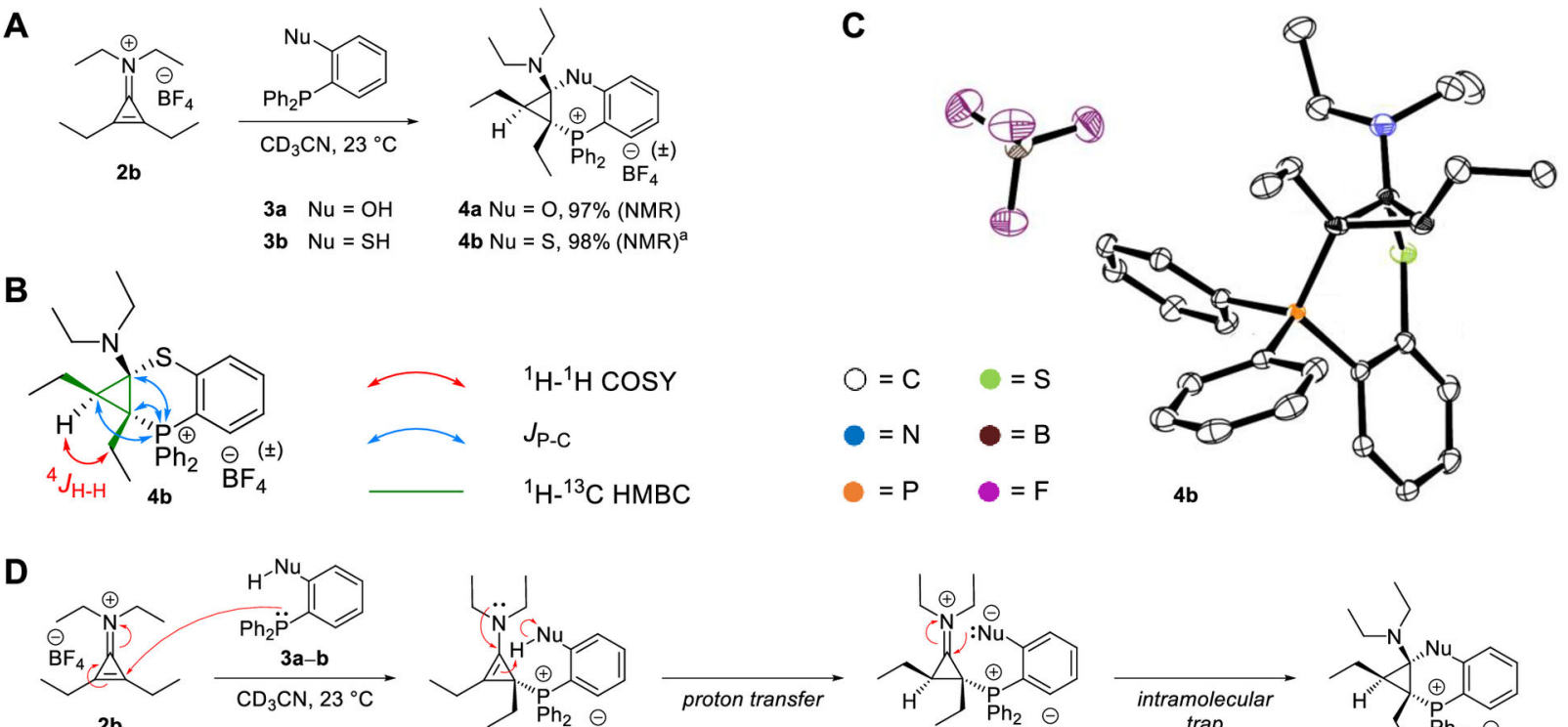

2b

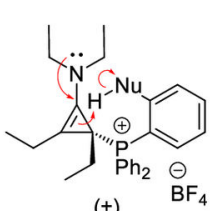

proton transfer

$( \pm)$
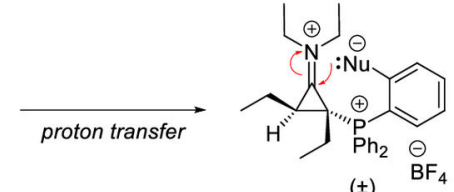

intramolecula

(士) $\quad \mathrm{BF}$
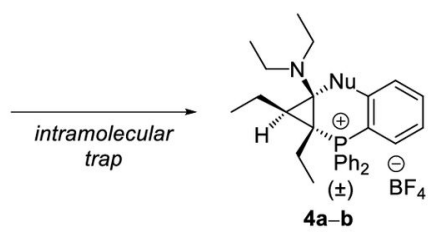

Figure 3.

The $\mathrm{CpN}^{+}$-phosphine ligation. (A) $\mathrm{CpN}^{+} \mathbf{2} \mathbf{b}$ reacts with phosphines $\mathbf{3 a}-\mathbf{b}$ to yield cyclopropane-phosphonium adducts $\mathbf{4 a}-\mathbf{b}$. (B) Structure of $\mathbf{4 b}$ as suggested by correlative NMR analyses. Key connections are indicated. (C) ORTEP diagram of $\mathbf{4 b}$ showing thermal ellipsoids at the 50\% probability level (hydrogens have been omitted for clarity). (D) Proposed mechanism for the formation of $\mathbf{4 a}-\mathbf{b}$. Phosphines $\mathbf{3 a}-\mathbf{b}$ react with $\mathbf{2 b}$ via a conjugate addition. Subsequent intramolecular proton transfer and nucleophilic attack

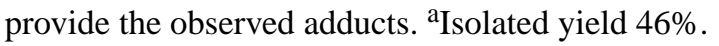




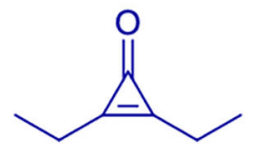

$\triangle$

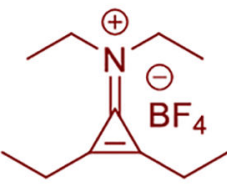

$\triangle$

$$
t=72 \mathrm{~h}
$$

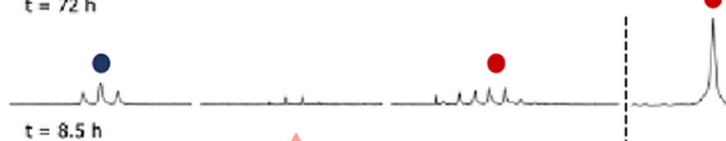

2.<smiles>Pc1ccccc1S</smiles><smiles>CC/C=C(\CC)C(=O)O[C@H]1CCCC[C@H]1P</smiles>

$( \pm$

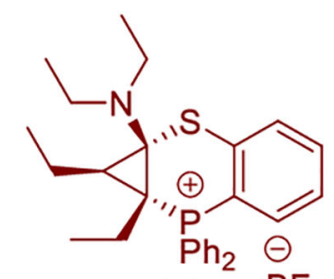

$( \pm)$
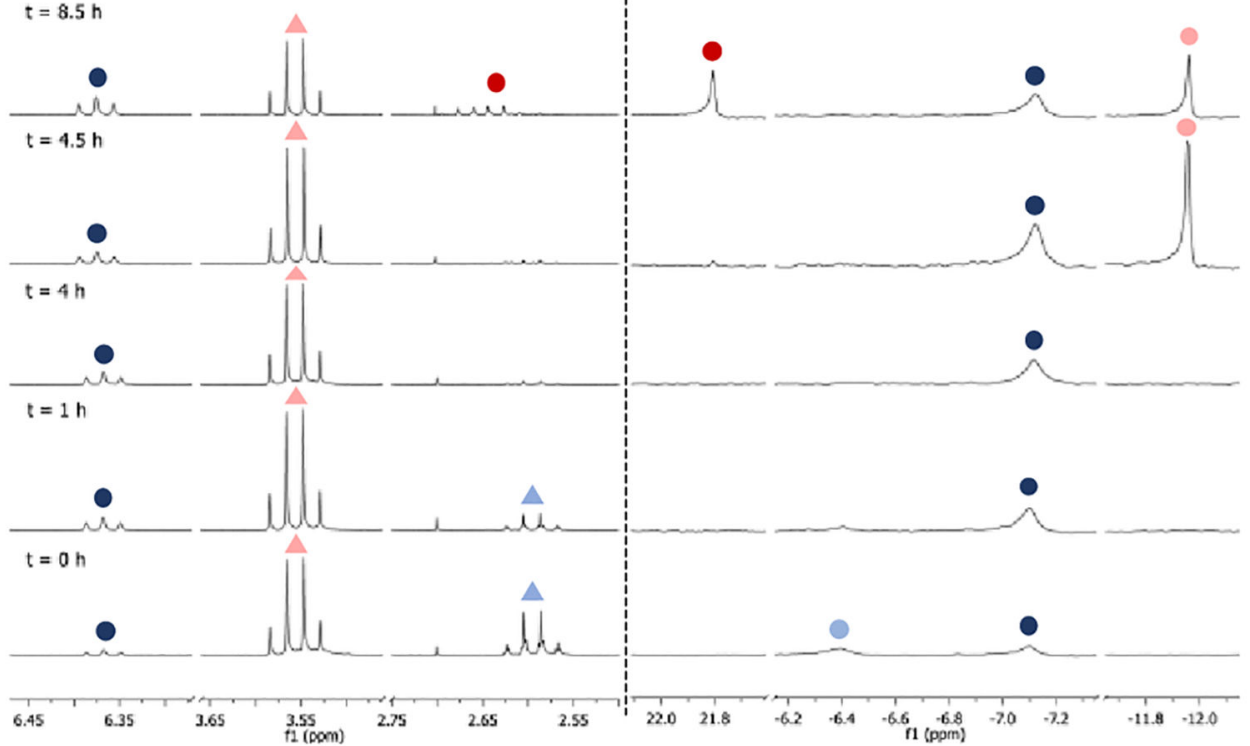

Figure 4.

Compatible $\mathrm{CpO}$ - and $\mathrm{CpN}^{+}$-phosphine ligations. $\mathrm{CpO} \mathbf{1 b}$ (blue triangle), $\mathrm{CpN}^{+} \mathbf{2 b}$ (pink triangle), and phosphine $3 \mathbf{e}$ (light blue circle) were mixed in $20 \% \mathrm{C}_{6} \mathrm{D}_{6} / \mathrm{CD}_{3} \mathrm{CN}$. A single adduct formed (dark blue circle). After 4 h, phosphine 3b (light pink circle) was added, providing the second adduct (red circle). Full spectra are provided in Figures S30 and S31. 


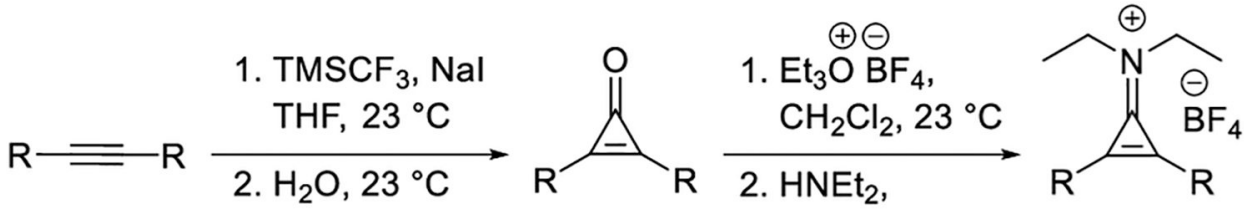

$\mathrm{R}=\mathrm{Me}$

1a $R=\mathrm{Me}, 81 \%$

$\mathrm{CH}_{2} \mathrm{Cl}_{2}$,

2a R $=$ Me, $22 \%$

$\mathrm{R}=\mathrm{Et}$

1b R = Et, $90 \%$

O-23 ${ }^{\circ} \mathrm{C}$

2b R $=E t, \quad 35 \%$

2c $\mathrm{R}=\mathrm{Ph} \quad 14 \%$

Scheme 1.

Synthesis of $\mathrm{CpN}^{+}$probes 
Table 1.

$\mathrm{CpN}^{+}$species reactivity with functionalized phosphines
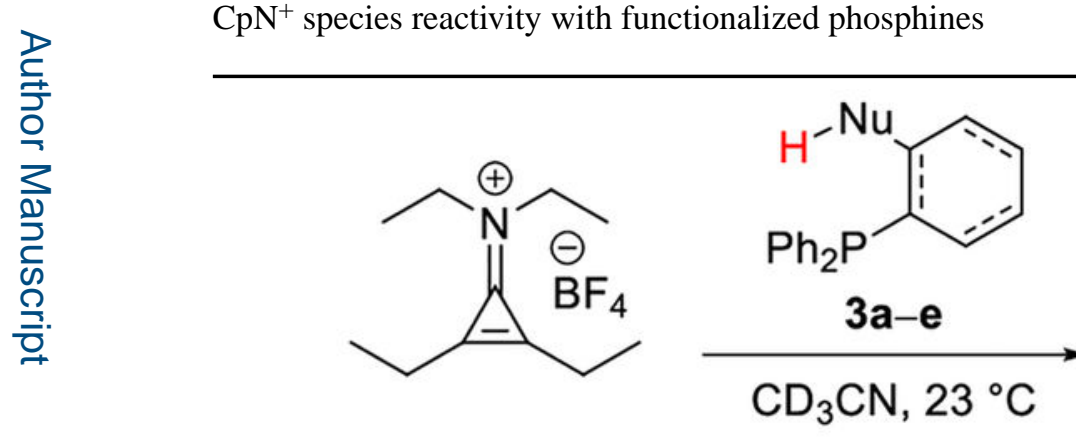

2b

$3 a$

$3 b$

$3 c$

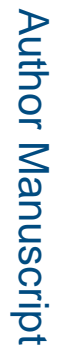

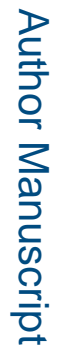

\begin{tabular}{|c|c|c|c|}
\hline & & & $4 a-e$ \\
\hline & Phosphine & $\mathrm{p} K_{\mathrm{a}}$ & $k_{2}\left(\mathrm{M}^{-1} \mathrm{~s}^{-1}\right)$ \\
\hline $3 a$ & & $\sim 10$ & $7.1 \pm 0.8 \times 10^{-3}$ \\
\hline $3 b$ & & $\sim 6$ & $2.3 \pm 0.3 \times 10^{-3}$ \\
\hline $3 c$ & & $\sim 31$ & N.R. \\
\hline $3 d$ & & $\sim 21$ & N.R. \\
\hline $3 e$ & & $\sim 16$ & N.R. \\
\hline
\end{tabular}

